\title{
Over The Counter Product Indicator
}

National Cancer Institute

\section{Source}

National Cancer Institute. Over The Counter Product Indicator. NCI Thesaurus. Code C93615.

Specifies whether a product is available without a doctor's permission, order or prescription. 